\title{
USING AN IPAD IN GERMAN LANGUAGE CLASSES
}

\author{
Urška Godler \\ Hruševec Šentjur Primary School, Šentjur, Slovenia
}

\begin{abstract}
The pupils at the Hruševec Šentjur primary school learned the German language by using iPads, applications and online interactive exercises. They learned about rooms in the house, furniture, equipment and prepositions. The goals were: to learn German words together with their articles, use prepositions and describe a house or apartment and a room, which was the final and most desired goal. All the pupils were actively engaged and motivated and managed to achieve all the set goals.
\end{abstract}

Key words: rooms, furniture, equipment, prepositions “Wechselpräpositionen”, iPad, 24/7 Tutor, Tellagami, interactive exercises, Hot Potatoes programme.

\section{Introduction}

This analysis describes how the iPad made learning the chapter Hier wohne ich easier for the pupils. The pupils were acquainted with the vocabulary via a Power Point presentation, afterwards reinforcing the vocabulary using the 24/7 Tutor iPad application. They were also acquainted with the prepositions and articles in the $3^{\text {rd }}$ case using a photo and table. The pupils reinforced their vocabulary knowledge through online exercises and the Hot Potatoes programme. They also learned how to form sentences needed for the description of a room by using flash cards, made in the Quizlet programme, and using the Tellagami application. Finally, the pupils learned how to describe their room. They used iPads for assistance.

The topics and grammar points listed above are aimed at primary school pupils, but they are also appropriate for secondary school students. They are part of the Common European Framework of Reference for Languages, level A2. The described didactical approach encourages listening, reading, writing and speaking in an attractive manner. By using methods and techniques described below, the learning was more effective.

\section{Methods and Techniques}

\section{Learning vocabulary with a Power Point presentation}

The teacher first presented the rooms, furniture and equipment of a house or apartment in German using a Power Point presentation with pictures. The pupils took notes, entering the information into their notebooks or iPads using the Notes application. 


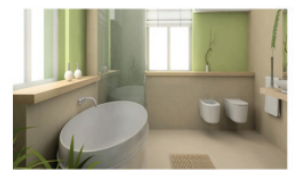

das Bad



die Küche

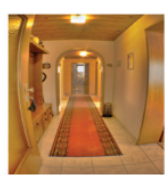

der Flur

Figure 1: Rooms in the house (some examples).

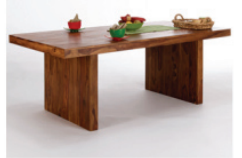

der Esstisch

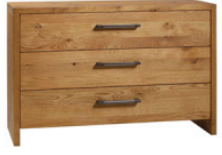

die Kommode

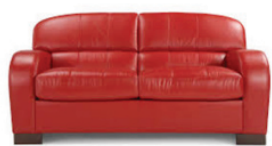

das Sofa

Figure 2: Furniture and equipment (some examples).

Vocabulary reinforcement with the 24/7 Tutor iPad application

When one hears and writes down words, one has to reinforce them. The pupils did so using the 24/7 Tutor iPad application, first at school and then at home. The counterparts of the German words were given in English.

\section{$24 / 7$}

TUTOR

Figure 3: 24/7 Tutor iPad application.

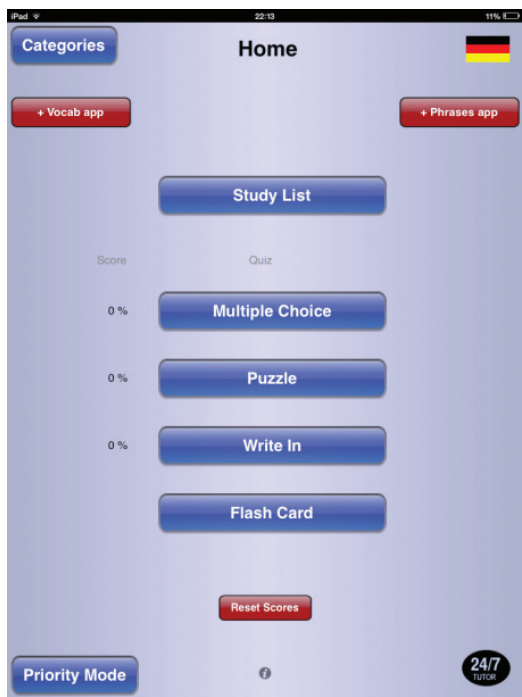




\section{Figure 4: Menu of the 24/7 Tutor application.}

This application offers a number of learning possibilities. The first task is called the Study List. This comprises a list of words with an audio recording and English translation of each word. The pupil can tap on the word, listen to the German pronunciation, repeat it and view the translation in English. This enables pupils to reinforce the pronunciation and meanings of words.

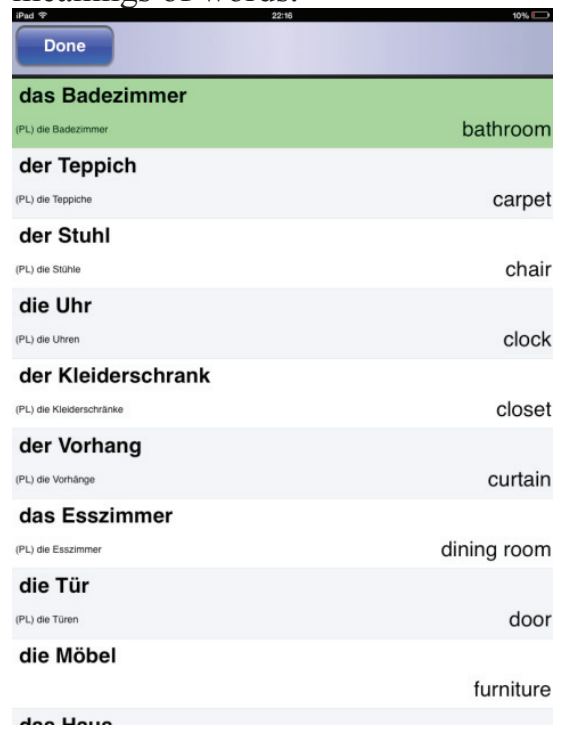

Figure 5: Study List in the 24/7 Tutor application.

The next task is the Multiple Choice task, where the iPad displays a German word to the pupil who has to select the correct English meaning. The pupil can also listen to the pronunciation of the word, afterwards choosing an answer by tapping the correct answer and receiving feedback, whether the answer was correct (highlighted in green). If the answer was wrong, the application shows this by highlighting the wrong answer in red and highlighting the correct answer in green.
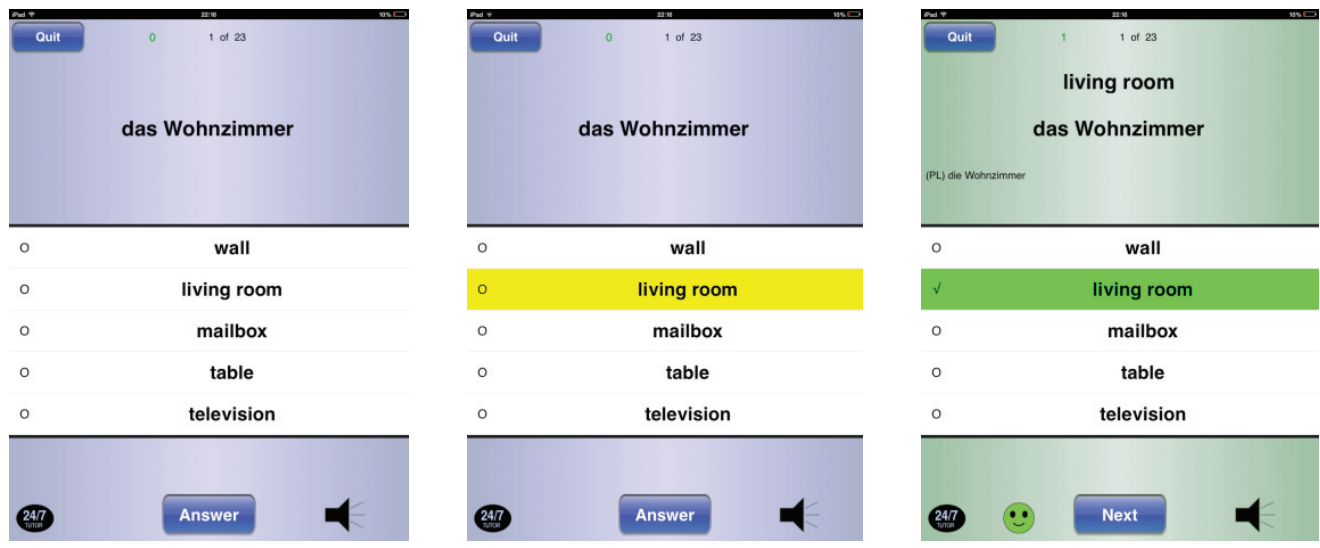


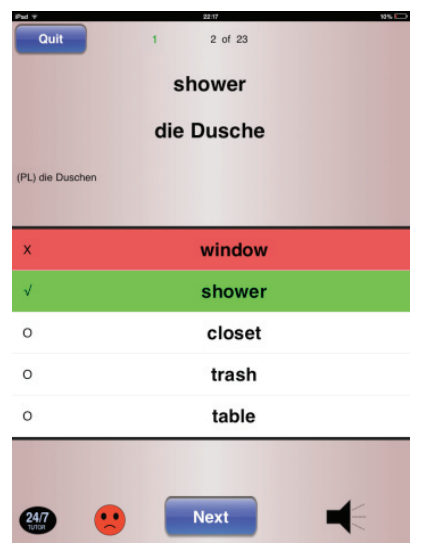

Figure 6: Multiple Choice in the 24/7 Tutor application.

Another possibility for reinforcing vocabulary is the Puzzle option, where the pupil enters the word in the empty spaces. The application provides feedback in the same manner as mentioned above.
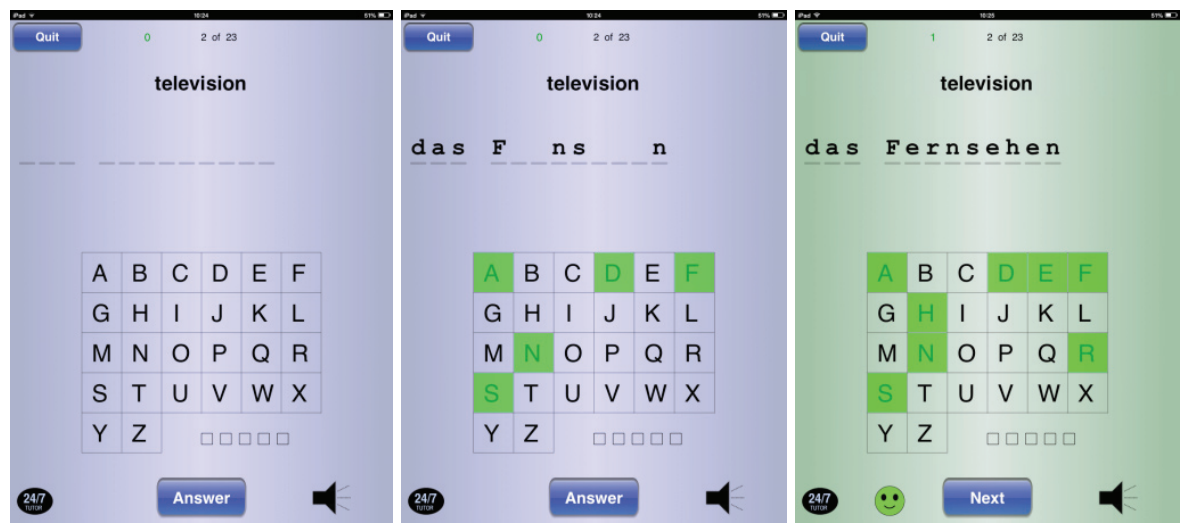

Figure 7: Puzzle in the 24/7 Tutor application.

During these exercises, the application adds points and in the end, provides information as a percentage to inform the pupil of their success.

\section{Learning and reinforcement of prepositions and the $3^{\text {rd }}$ case}

After the pupils reinforced the vocabulary, they learned dual German prepositions (Wechselpräpositionen) and were given a detailed explanation of the German cases. They focused on the $3^{\text {rd }}$ case.

The pupils reinforced their knowledge of prepositions through online interactive exercises. Two examples of such exercises are shown below. In the first exercise, pupils select which preposition is suitable for the given photo and word. In the second exercise, the pupil repeats the preposition and how it's written by using the photo and writing the preposition into the crossword. 

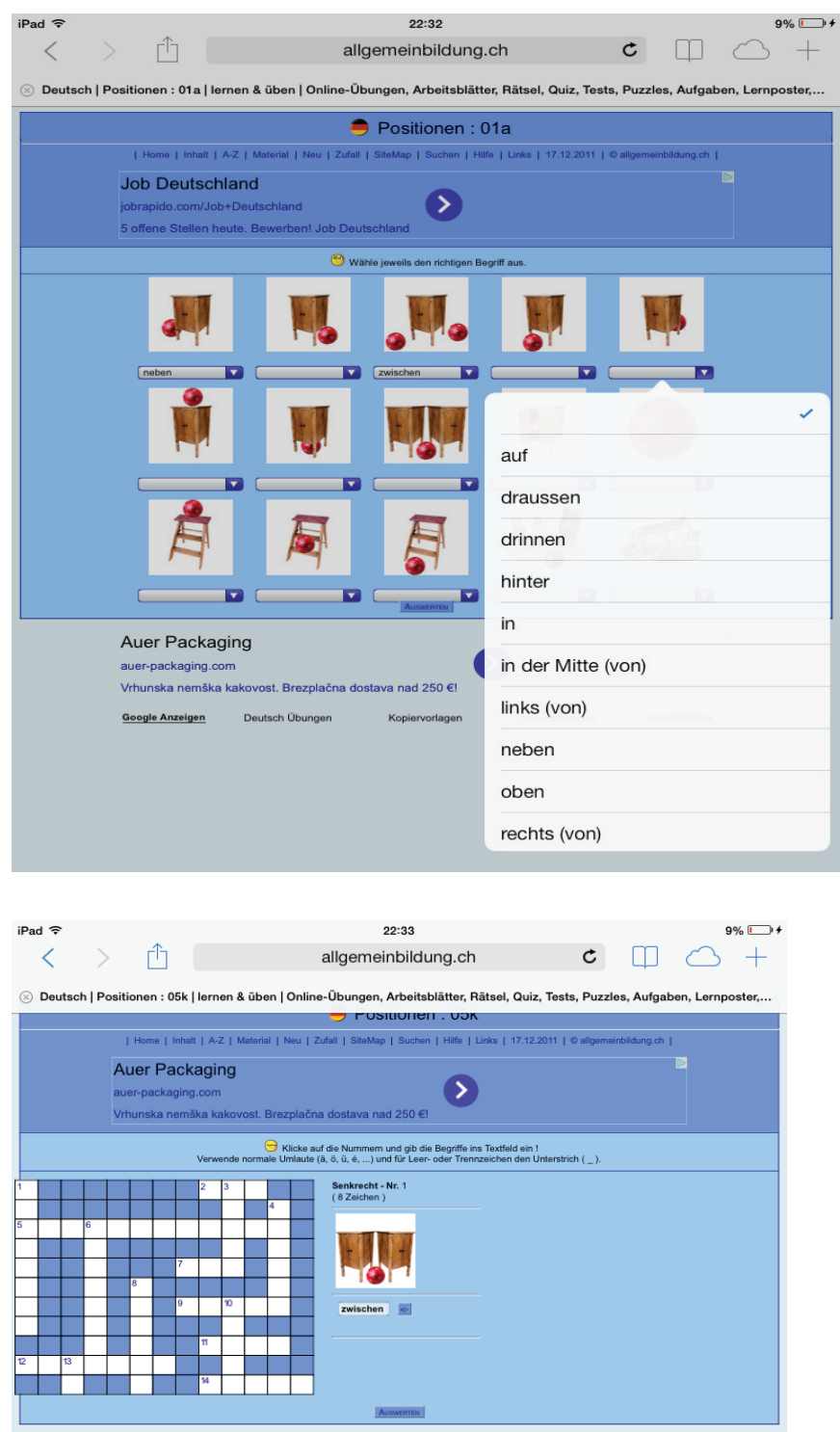

Job Deutschland

jobrapido.com/Job+Deutschland

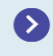

Google Anzelgen Deutsch Ubungen Kopiervorlagen Ubungen Grammatik Online Obungen

\begin{tabular}{|c|c|c|c|c|c|c|c|c|c|c|c|c|c|}
\hline$Q$ & W & $\mathrm{E}$ & & $\mathrm{R}$ & $\mathrm{T}$ & & Z & u & & 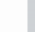 & O & $P$ & $\otimes$ \\
\hline A & & & & F & & & $\mathrm{H}$ & & & K & & & Prijelaz \\
\hline 仓 & $Y$ & $x$ & & c & V & & & $\mathrm{N}$ & 1 & & ! & $?$ & 仓 \\
\hline 2123. & & 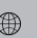 & & & & & & & & & & .3123 & 罪 \\
\hline
\end{tabular}

Figures 8 and 9: Interactive exercises to reinforce prepositions. 
The pupils reinforced the $3^{\text {rd }}$ case using the Hot Potatoes programme. It is a multiple choice exercise based on reading comprehension.

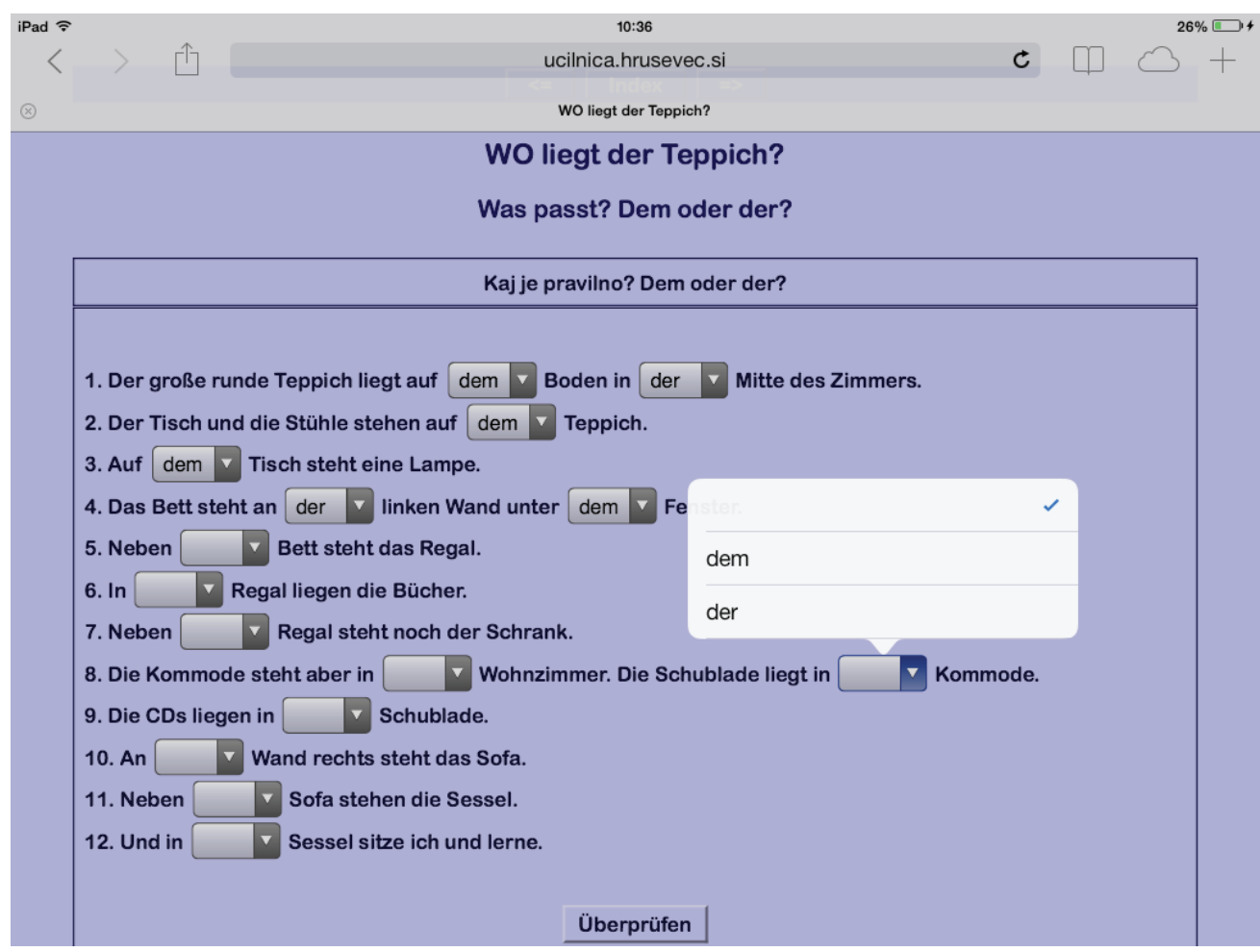

Figure 10: Exercise in the Hot Potatoes programme to reinforce the $3^{\text {rd }}$ case.

Forming sentences with flash cards in the Quizlet programme

The pupils formed sentences using a preposition, the $3^{\text {rd }}$ case and vocabulary for furniture. They used flash cards made in the Quizlet programme. The cards have a task on one side, the pupil takes a look at it and performs the task. The answer is shown by tapping on the iPad screen. The card turns around and the pupil can check whether the answer was correct or not. 


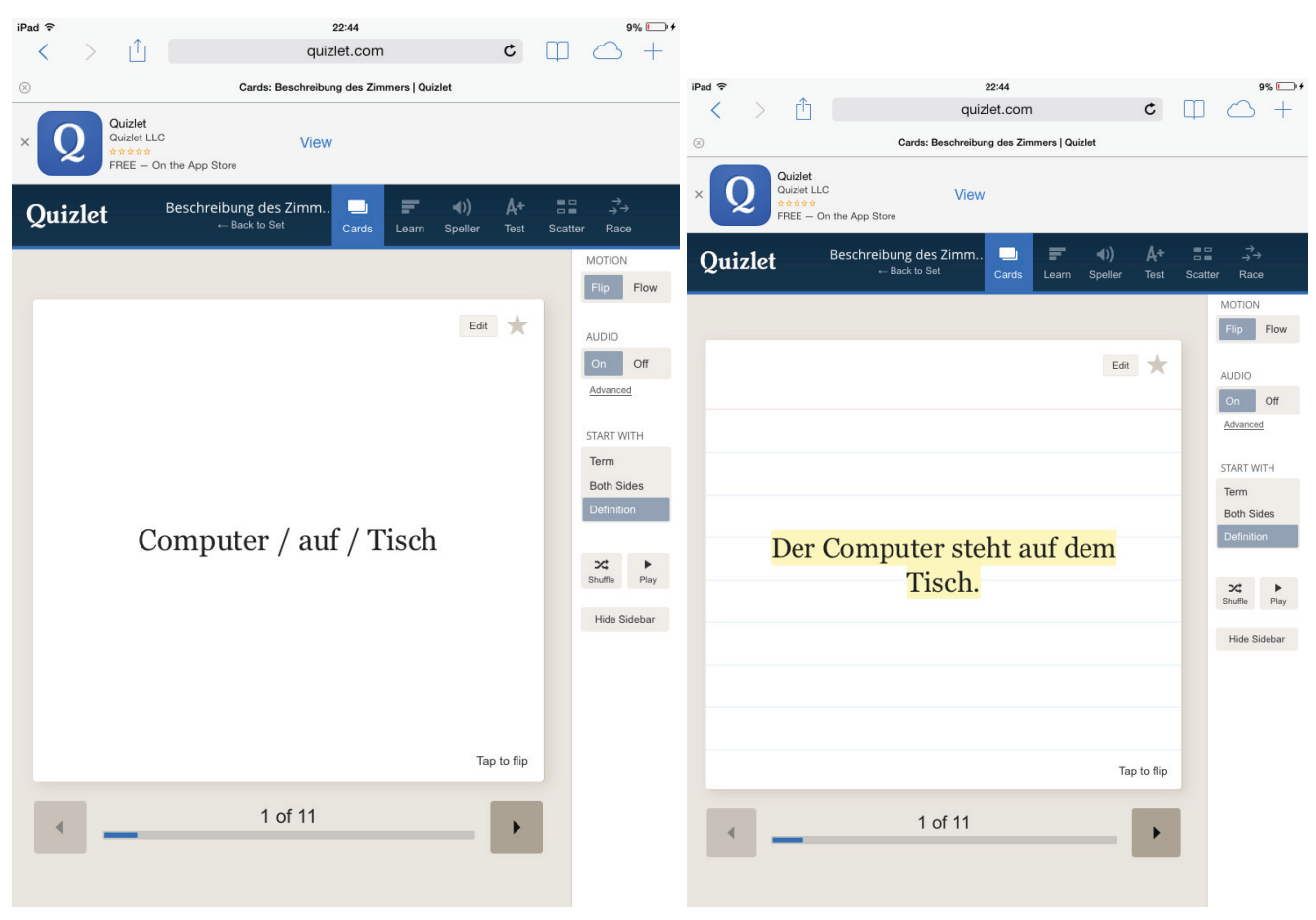

Figures 11 and 12: Forming sentences using flash cards (task and solution).

\section{Tellagami iPad application}

This is an application for creating fun messages that can be sent to someone to have a nice day. In the classroom, the application was used for didactic purposes. The application allows one to set create a human being (gender, skin colour, eye and hair colour, size of the head, clothes and shoes), the emotional state (happy, sad, surprised, angry, scared or silly) and a background. The pupil can take a picture of the room, he or she wants to present as the background, or choose a photo from the iPad library as the application offers some photos for free. After selecting the human being and background, the pupil can record his or her speech (in this case describing the room in the background) and listen to the recording. The pupil can also write the text the created human being says.

The pupils experienced some technical problems (more in the discussion) and had to find their own way. The pupils set the human being and the background. Among the two options offered by the application, they chose those two that showed two rooms in a house. Using the picture the pupils verbally described the locations of the items, thereby learning quite a lot. This application provided everything they needed to achieve their main goal to describe their house or apartment and their room. 


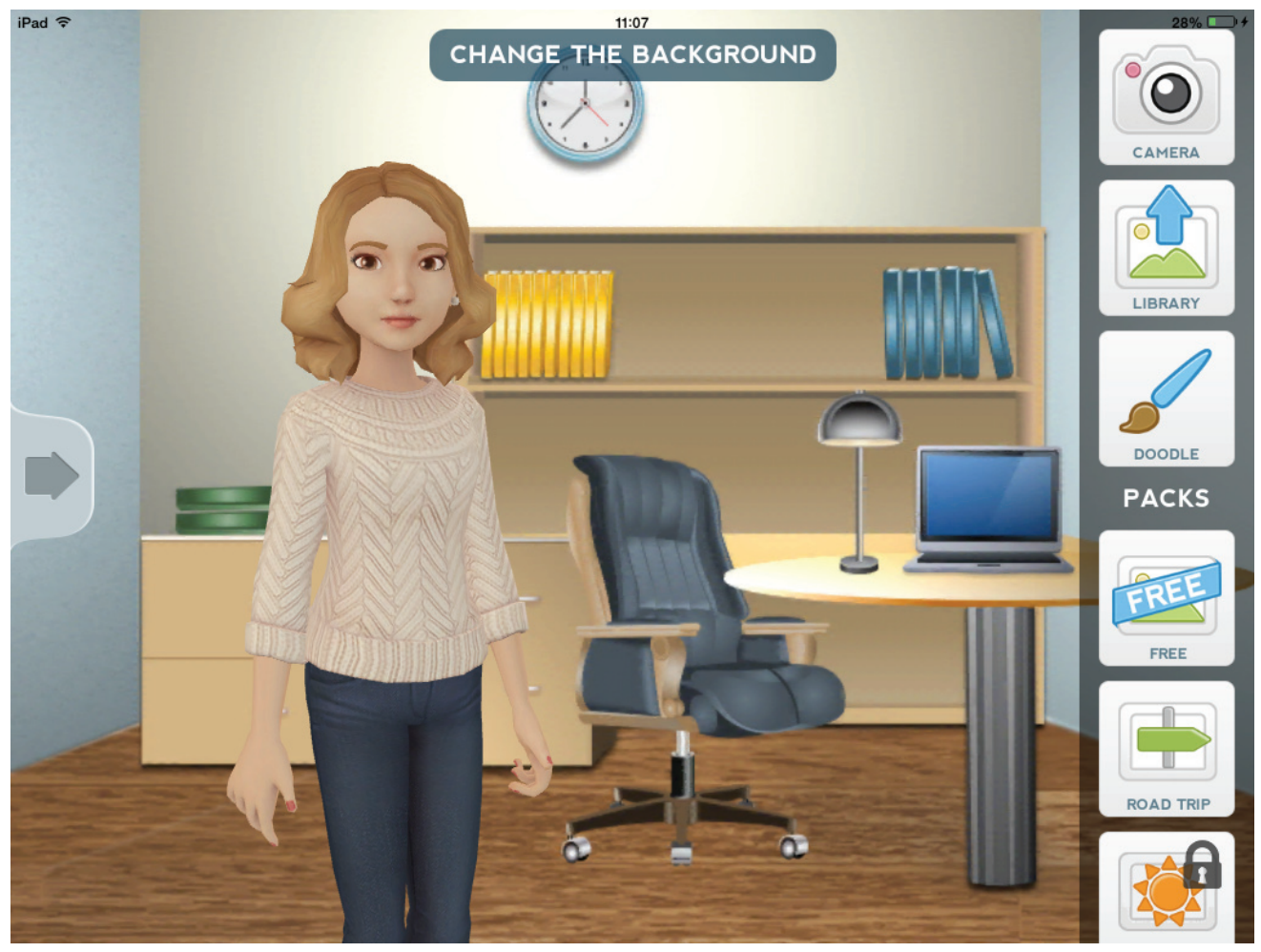

Figure 13: The Tellagami application: woman in an office, in a good mood.

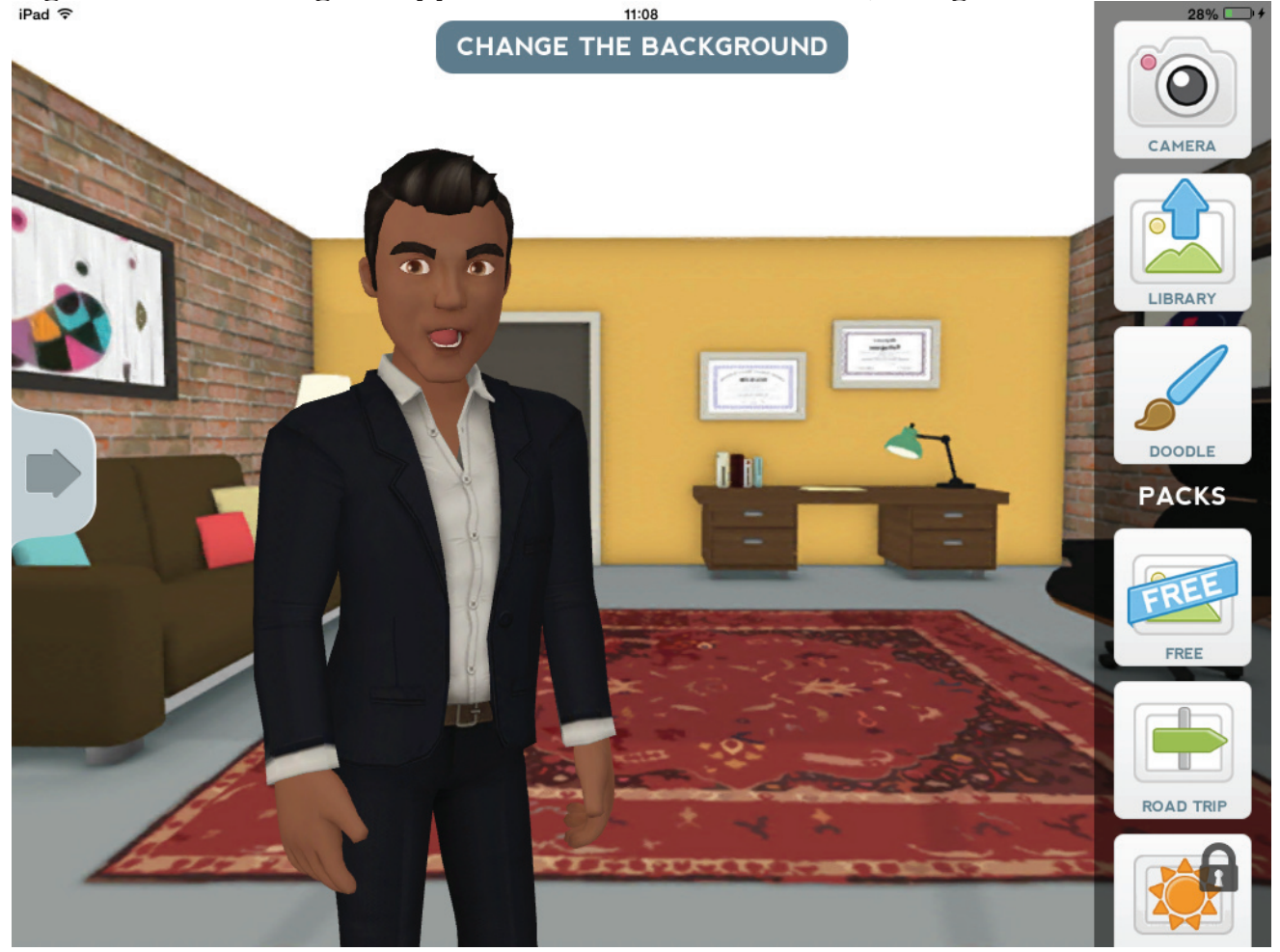

Figure 14: The Tellagami application: a surprised man in the living room. 


\section{Description of a house or apartment and a room}

The pupils then used the knowledge gained using the techniques, methods and applications described above through conversation practice. Each pupil prepared a description of his or her house and room, presenting where he or she lived, how many floors and which rooms the house or apartment had. The main emphasis of the conversation practice was the description of the pupil's room (location, colour, size, where the things in the room were located and what the pupil did in the room). The conversation presentation lasted for 5 minutes. The pupils used iPads to take a picture of their house or apartment and room and prepare a presentation comprising conversation practice using their iPads.

\section{Educational Implications}

Firstly, the Tellagami application has advantages and disadvantages. As mentioned above, this application offers immense possibilities. One is the entry of text you want to communicate. Initially, the idea was for the pupils to describe their rooms and enter their text into the application. After pressing the "play" button, the created human being should have read out the text. Unfortunately, the application was made for English-speaking areas and, therefore, the human being can only speak English and not German. Therefore, German sentences were read out as an English text and thus made no sense. Another problem was the lack of audio when the pupils recorded the room description and pressed the "play" button.

Nevertheless, the application is definitely useful. When learning German, the pupils used the application as a picture. When learning English, the application can be fully used to describe a room. Moreover, the application can also be used to describe people (appearance and character) in English as well as in German. Because the pictures and animations are so attractive, the application definitely encourages the development of speech.

Secondly, such an approach definitely has its didactic added value. The results of learning using iPads were very good. The pupils memorized the vocabulary faster and they understood the grammar better. They learned the subject matter quickly and fortified their comprehension using the applications and interactive exercises. Moreover, they actively participated in the learning process and were therefore highly motivated. Because of their strong motivation, they were able to achieve the active level of language (writing and speaking) sooner than they would use ordinary methods. Knowledge was gained in a qualitative manner. A video displaying the pupils' learning process step by step can be seen at: http://www.youtube.com/watch?v=0VRukp5mbw4.

Finally, the use of all the applications and interactive exercises mentioned above is definitely recommendable for those desiring to learn about rooms, furniture and equipment. Knowledge is guaranteed - even with those pupils who don't exactly prefer classical textbooks and workbooks.

Learning using applications and online exercises definitely has a lot of advantages. This different and new approach enables pupils to learn, repeat and reinforce knowledge. Pupil response to this kind of method has been very positive. Pupils enjoy working with applications and programmes and are motivated, thus learning much more. This approach allows pupils who don't find textbooks and workbooks attractive to learn more easily and makes learning more enjoyable. They learn the same subject matter in a completely different way. 
Teachers always have to be careful to enable sufficient communication and independent writing in foreign language lessons, because language knowledge is best developed through real, verbal communication. The gaining of a sufficient level of knowledge to be able to communicate requires a lot of work. The presented applications and exercises will aid pupils, both visual and auditory types of learners, and encourage experiential learning.

\section{Acknowledgments}

The authors acknowledge the support of the Ministry of Education, Science and Sport of Republic of Slovenia and European Social Fund in the frame of the Project: "Innovative pedagogy 1: 1 in the light of competences of the 21 st century" on Faculty of Natural Sciences of University of Maribor.


\section{References}

Motta, G. (2005). Wir 3. Nemščina za začetno učenje [Wir 3. German for beginners]. Ljubljana: Založba Rokus d.o.o.

Motta, G. (2011). Magnet 2. Učbenik za nemščino v osmem in devetem razredu osnovne šole [Magnet 2. Workbook for the German language in the $8^{\text {th }}$ and $9^{\text {th }}$ grade of primary school]. Ljubljana: Založba Rokus Klett d.o.o.

Wechselpräpositionen. RetrievedApril2,2014, from http://www.allgemeinbildung.ch/fach=deu/ Positionen_01a.htm; http://www.allgemeinbildung.ch/fach=deu/Positionen_05k.htm

Quizlet. Retrieved April 2, 2014, from http://quizlet.com/38656024/flashcards Godler, U. (2014). Inovativna pedagogika 1:1, Retrieved April 15, 2014, from http://www.youtube.com/watch?v=0VRukp5mbw4

Received 30 June 2014; Accepted 15 August 2014

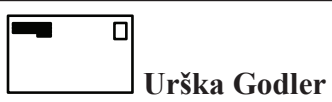

German professor and political scientist, German teacher, the Hruševec Šentjur Primary School, Gajstova pot 2a, 3230 Šentjur, Slovenia.

E-mail: urska.godler@hrusevec.si

Website: http://www.hrusevec.si/ 